\title{
Ectopic Ureterocele in Infancy and Childhood Review of Literature and Report of 4 Cases
}

\author{
Dr. Yasin Idweini, MD, Ph.D. \\ Consultant and Chairman of Urology department \\ Al-Bashir Teaching Hospital-Amman- Jordan \\ yasin_idweini@hotmail.com
}

\begin{abstract}
Congenital ureteral malformations are commonly known, and range from complete absence to duplication of the ureter. Ureterocele is considered as structural anomaly of ureter; which is a cystic dilatation of the terminal ureter. It may be either intravesical or ectopic; in the later case, some portion is located at the bladder neck or in the urethra. Intravesical ureteroceles are, most often, associated with single ureters, whereas ectopic ureteroceles nearly involve the upper pole duplicated ureters. Ectopic ureteroceles are 4 times more common than those intravesical. In general, ureteroceles occur 7 times more in girls than in boys, and about $10 \%$ of cases are recorded to be bilateral. Ureteroceles have varied effects in terms of obstruction cases; reflux, continence and renal function; hence, each ureterocele must be managed on individual basis rather than by a simple algorithm. They may cause severe obstruction that requiring urgent attention, or they may be asymptomatic and of no clinical significance. Should they are incorrectly treated, the adverse outcomes thereof may not be appreciated for years to come. Appropriated management is predicated by being aware of the relevant embryology, anatomy and physiology and all related variants.
\end{abstract}

\section{INTRODUCTION}

\section{Definition}

A ureterocele is a cystic dilatation of the terminal segment of the intravesical ureter.

\section{Incidence}

On autopsy, they occur in 1 in 500 cases. They are 4 to 7 times more frequent in females, and more common in white people. (1).

Ureteroceles are bilateral in $10 \%$ of cases, $80 \%$ are associated with the upper pole ureter of a duplex system and $60 \%$ have the orifice located ectopically in the urethra. $(1,2)$.

\section{Classification}

Ureteroceles are classified as being either intravesical (within the bladder) or ectopic (some portion extends beyond the bladder neck).Other common encountered terms include; stenotic (intravesical with a small orifice), sphincteric (ectopic, with the orifice within the urethral sphincter) sphincterostenotic (same as sphincteric with a stenotic orifice) and cecoureterocele (some parts extend beyond the bladder neck, but the orifice is in the bladder). (3). Blind (extends under the trigone and into the bladder outlet, no opening is identifiable, the dilated ureterocele can cause severe bladder outlet obstruction). Non-obstructive (Lies entirely within the bladder, and has a large opening which does not impede drainage of the ureterocele). (3; 4). In a series of 60 ureteroceles: $40 \%$ were stenotic, one third sphincteric, $6 \%$,sphincterostenotic, $5 \%$ blind, $5 \%$ non-obstructive, and $5 \%$ a caecoureterocele(5). 


\section{Etiology}

Uretercele has been attributed to delayed or incomplete canalization of the ureteral bud that leading to an early prenatal obstruction and expansion of the ureteral bud prior to its absorption into the urogenital sinus(6).

\section{Embryology}

A ureterocele is a ballooning of the terminal ureter as it enters the bladder. The embryology of ureteroceles is not as neatly explained and there are several theories. Persistence of a thin membrane of opposing urogenital and ureteric epithelium at the insertion of the ureter into the bladder may provide an explanation for obstructive ureteroceles (7). Another possibility is late arrival of the ureteric bud into the bladder allowing the ampullary origin of the ureteric bud to over-expand even before it has reached the bladder (6).

At 37 days gestation Chwalle's membrane, a two layered cell structure,transiently divides the early ureteric bud from the urogenital sinus. (Chwalle, 1977) The stenotic orifice commonly seen in the ureterocele and the dilatation results from incomplete dissolution of Chwalle's membrane and abnormal muscular development; without the appropriate muscular backing , the distal ureter assumes a balloon morphology (Tokunaka et al 1981). Another theory implicates a developmental stimulus responsible for bladder expansion acting simultaneously on the intravesical ureter. (8).

\section{Clinical Presentation}

The most common presentation is represented by urinary tract infection in the first few months of human life. Some are detected incidentally via antenatal ultrasonography. (9). In the pediatric population, ureteroceles may present with different clinical images, and the severity of the renal damage is greater in infants than in adults.Ureterocele, an anomaly of ureteric budding, is likely a component of a spectrum of anomalies including vesicoureteral reflux and ureteral duplications. Both have been confirmed to have a genetic and familial basis. The familial occurrence of ureterocele was first described in 1936 by Riba (10) and reinforced with further studies $(11,12)$. All of these familial cases, despite their rarity, raise the issue of the genetic origin of ureteroceles, such as duplication and VUR, obvious that molecular genetic studies will give important details of urinary tract morphogenesis in the near future. The Severity of hydronephrosis and associated complications with ureteroceles generally appear to be more significant in children than in adults. Whereas this pathology can lead to important complications, early diagnosis is strongly recommended (13).

Some patients may have a palpable abdominal mass secondary to an obstructed kidney. Although urethral obstruction is rare, the most common causes of urethral obstruction in girls are urethral prolapse of ureterocele (14).

\section{DiAgnosis}

\section{Abdominal Ultrasound}

It is strongly recommended be performed first. This will usually reveal a well-defined cystic intravesical mass in the posterior portion of the bladder. A dilated proximal ureter may also be seen. Most often there should be a duplex kidney on the ipsilateral side, and the upper pole may be dysplastic. (15). Sonography is the modality of choice for prenatal screening of fetal anomalies. It provides cost-effective, real-time imaging, has a high- resolution capacity and is safe as to the fetus and mother.

However, in some circumstances like maternal obesity, oligohydramnious or unfavorable position of the fetus, the sonography is limited (16-20). 


\section{Renal Scan}

is used to determine the relative function of all the renal segments and the washout time as well. (21).

\section{Urogram (IVU)}

This is not mandatory, but if performed it may reveal a negative shadow of the ureterocele within the bladder, a drooping lily sign in the kidney (down ward displaced lower pole), a lower pole collecting system with missing upper pole infundibulum and a laterally displaced lower pole ureter that loops around the dilated upper ureter in the pelvis .Fig. (1).

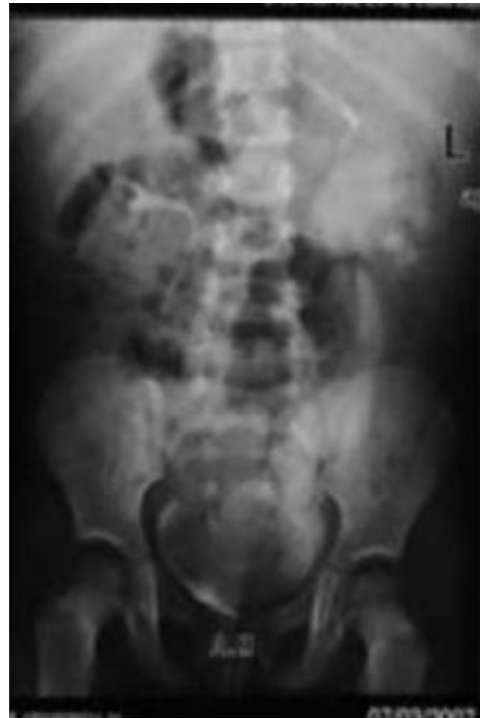

Fig1. IVU: Rt.ectopic duplex ureterocele

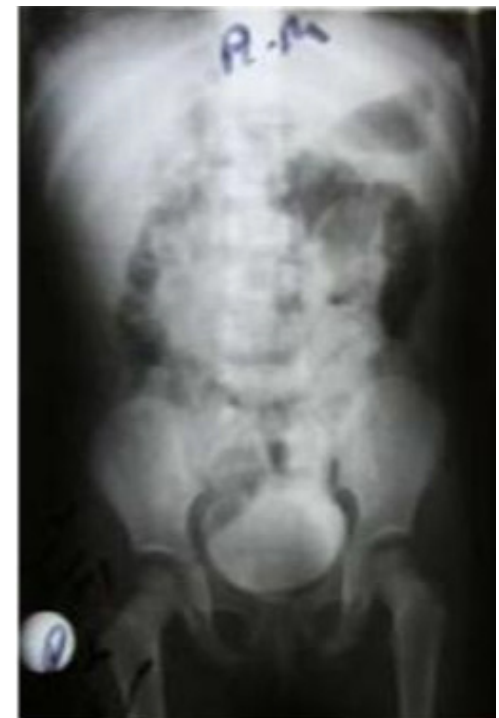

Fig2. VCUG: Rt.ureterocele Lt.VUR

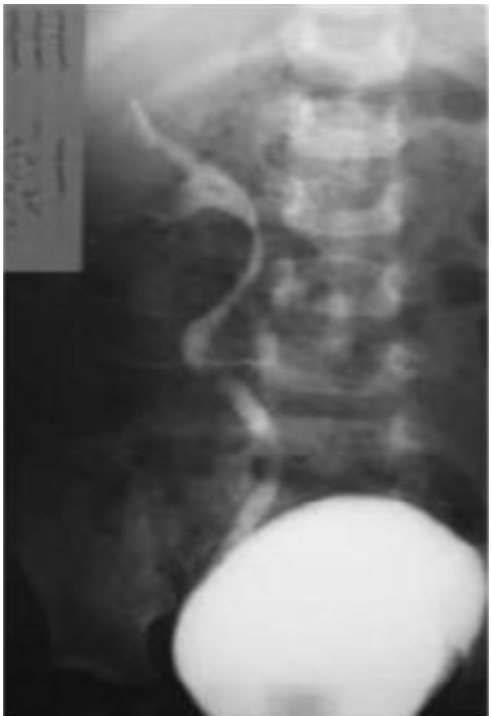

Fig3. VCUG Post Puncture of ectopic $R$ ureterocele: Ipsilateral. $R$ VUR

\section{Voiding cystourethrogram (VCUG)}

Must be performed in all patients. Up to $50 \%$ of the ipsilateral lower pole and $25 \%$ of the contralateral renal units will have vesicoureteral reflux. Fig. $(2,3) .(22)$

Also, the ureterocele can usually be seen as a round filling defect within the bladder on the initial filling films. (23).

\section{Cystoscopy}

Cystoscopic findings are variable. The ureterocele is usually seen only when the bladder is empty and the flank is being compressed. When the bladder is full, the ureterocele may become completely decompressed or it may appear as a bladder diverticulum in case of poor bladder wall backing is existed. In a duplicated system, the upper pole ureter will be associated with the ureterocele, the lower pole ureter will be seen above and lateral to the ureterocele, if already noticed.

\section{Treatment}

The type of treatment depends on the type of ureterocele and the mode of presentation. Most patients require surgery, which ranges from endoscopic puncture to complete open reconstruction. If the patient presents with sepsis secondary to obstruction, immediate drainage of the kidney is necessary. Mostly, endoscopic puncture 


\section{Ectopic Ureterocele in infancy and childhood: Review of literature and report of 4 cases}

of the ureterocele is the first step. This is a definitive procedure used in $90 \%$ of intravesical ureteroceles cases, whilst $50 \%$ of ectopic ureteroceles. $(24 ; 25)$

\section{Endoscopic decompression}

Endoscopic management is the easiest way to achieve ureterocele decompression in neonates and infants, rather than extensive trigonal surgery which involves risks of damaging the bladder function in infants. It seems to be the approach of choice of intravesical duplex ureteroceles, whereas it comprises the definitive treatment for about half of ectopic ureteroceles (26-28) Technical reasons might partly explain the different success rates. The best technique involves making an incision or puncture in the intravesical portion of the ureterocele, just above the level of the bladder wall (29) to create a valve mechanism that prevents the development of VUR in the punctured moiety. The main criticism of ureterocele puncture, as a treatment modality, is the need for further surgery, despite adequate decompression. In a meta-analysis of 912 patients undergoing endoscopic treatment of their ureteroceles $47 \%$ went on to have further surgery (24).The most common indication for re-operation is VUR. This can affect half of the patients having a ureterocele puncture (30) and commonly affects the upper pole at about one third of patients (31). Ureterocele puncture can result in resolution of some pre-existing VUR (32). Treatment of VUR following ureterocele puncture has usually been performed via reconstruction. However, the minimally invasive approach of ureterocele puncture has been extended, by some groups, to include the treatment of VUR, which witnessed success rates at 60-70\% reported for cystoscopic injection therapy (32-33).Antenatal diagnosis of ureteroceles opens the possibility of antenatal intervention for ureteroceles. Puncture of ureterocele may be considered in utero that witness features of bladder out let obstruction; for example where oligo-or anhydramnios are available. There are case reports of successful foetal intervention (34-37). If endoscopic puncture fails, then open reconstruction needs to be performed. If there is no function in the upper pole moiety, then upper pole nephrectomy is performed, usually laparoscopically (38). A further modification is represented by performing upper pole hemi-nephrectomy laparoscopically. This is a technical difficult procedure even for an experienced laparoscopic surgeon. Conversion to open is required in up to $12.5 \%$ cases, perirenal collections are seen in a fifth, and it is not yet clear if the re-operation rate is comparable to open hemi-nephrectomy. (39-42)

\section{Upper tract surgery}

includes pyelopyelostomy or uretero-ureterostomy, ((anastomozing one ureter to other less diseased ureter is relatively simple and may avoid problems of ureterocele excision and bladder neck reconstruction(43).One of the advantages of uretero-ureterostomy is that it can be performed through a small incision. However, even this morbidity may be reduced by performing laparoscopic operation (44-46),all those procedures may be done in cases where the upper tract is functional, or heminephrectomy in the case of non- functioning or poorly functioning upper moieties (which comprise $70 \%$ of cases)

\section{Total reconstruction}

(It may includeall or part of the following: upper pole heminephrectomy, ureterocele excision or marsupialization of ureterocele, bladder base $\backslash$ neck reconstruction, and lower-pole ureter reimplantation): This procedure still representing the most effective and consistent approach for achieving single-stage case (surgical therapy) of

VUR (47). Consequently it has been recommended that this procedure is to be limited to cases of preoperative multiple or high-grade V.U.R. (48-49) 


\section{Conservative management}

The criteria proposed for non operative management varies according to the presented clinical scenarios that are considered at lowest risk of complications such as UTls. Bladder outlet obstruction, severe hydronephrosis of the ureterocele moiety and high-grade (over grade 111) VUR are contraindications. (50).

It has been suggested that the scintigraphic drainage pattern might be more relevant for defining the presence of obstruction than that of the actual urinary tract dilation. Moreover, the conservative management might also be extended to cases of ureteroceles that have demonstrable moiety function, provided that there should be an adequate drainage (halftime $<30 \mathrm{~min}$ ) for the affected unit(51). Successful conservative treatment was reported by Direnna and Leonard ,a selected minority of their patients (with no lower pole or bladder neck obstruction, less than grade IV reflux, and upper poles that should be drained if they were functioning) had no infection and required no surgery after a median follow-up of five years.(50)

REPORT OF 4 CASES OF ECTOPIC URETEROCELE IN INFANCY AND CHILDHOOD AT AL-BASHIR HOSPITAL

\section{Purpose}

To record and evaluate the clinical presentation and functional evolution of 4 cases of ectopic ureterocele in infancy and childhood.

\section{Material and method}

The medical records of 4 cases of ectopic ureteroceles were reviewed by preoperative studies as ultrasound, voiding cystourethrography DMSA and IVU. They were admitted to the urology department at AL-Bashir Hospital between March 2001 to March 2008 and treated for ureteroceles.

\section{Results}

Four girls aged from 9 months to 12 years (mean 4 years) were treated for ureteroceles. All patients presented with urinary tract infection and outlet obstruction. The ureteroceles were on the Rt side in three patients and on the Lt Side in one. The ureteroceles were associated with complete duplicated urinary collecting system in 2 patients and single in two patients (one of them was incomplete duplicated urinary collecting system). The ureteroceles were opened into the bladder neck (ectopic) in 4 girls. Transurethral incision of the ureteroceles was done in 3 patients (two patients with single system, and one with ectopic ureterocele duplex system). Open excision of huge ureterocele (marsupilization) and ipsilateral heminephroureterectomy was done in one case. Puncture of ureterocele and ipsilateral heminephroureterectomy with non refluxing ureter was performed in another case.

They all remained asymptomatic and required no further treatment during follow up period of 24 months.

We divided our patients in two groups regarding the type of p-c system, associated V.U.R. and mode of treatment.

\begin{tabular}{|l|l|l|l|l|l|l|l|l|l|}
\hline & Age & Sex & $\begin{array}{l}\text { Type of } \\
\text { ureterocele }\end{array}$ & $\begin{array}{l}\text { Type of p-c } \\
\text { system }\end{array}$ & $\begin{array}{l}\text { Site } \\
\text { of } \\
\text { uret. }\end{array}$ & presentation & $\begin{array}{l}\text { V.U.R } \\
\text { Ipsil. }\end{array}$ & $\begin{array}{l}\text { V.U.R } \\
\text { Contral. }\end{array}$ & Treatment \\
\hline $\begin{array}{l}\text { Group } \\
\text { I }\end{array}$ & 9 months & Female & ectopic & $\begin{array}{l}\text { Rt } \\
\text { Incomplete } \\
\text { duplicated }\end{array}$ & Rt & $\begin{array}{l}\text { UTI+outlet } \\
\text { obst. }\end{array}$ & - & - & $\begin{array}{l}\text { Endos. } \\
\text { puncture }\end{array}$ \\
\cline { 2 - 9 } & 12 years & Female & ectopic & Single & Lt & $\begin{array}{l}\text { Recurrent } \\
\text { UTI }\end{array}$ & - & - & $\begin{array}{l}\text { Endos. } \\
\text { puncture }\end{array}$ \\
\hline
\end{tabular}

American Research Journal of Urology

Page 35 
Ectopic Ureterocele in infancy and childhood: Review of literature and report of 4 cases

\begin{tabular}{|l|l|l|l|l|l|l|l|l|l|}
\hline \hline $\begin{array}{l}\text { Group } \\
\text { II }\end{array}$ & 11 months & Female & ectopic & $\begin{array}{l}\text { Bil. } \\
\text { duplicated }\end{array}$ & Rt & $\begin{array}{l}\text { UTI+outlet } \\
\text { obst. }\end{array}$ & + & + & $\begin{array}{l}\text { Marsupilization } \\
\text { of ureterocele } \\
\text { +Heminephro- } \\
\text { ureterectomy }\end{array}$ \\
\cline { 2 - 8 } & 2.6 years & Female & ectopic & $\begin{array}{l}\text { Bil. } \\
\text { duplicated }\end{array}$ & Rt & $\begin{array}{l}\text { UTI+outlet } \\
\text { obst. }\end{array}$ & + & + & $\begin{array}{l}\text { Puncture of } \\
\text { uroterocele } \\
\text { +Heminephro- } \\
\text { ureterectomy }\end{array}$ \\
\hline
\end{tabular}

\section{DISCUSSION}

Ureteroceles are increasingly diagnosed by prenatal ultrasound studies. PrenatalU/S is capable of demonstrating both the hydronephrosis and the intravesical cystic dilatation; however, many ureteroceles are still diagnosed clinically as in our cases ( 3 cases presented with UTI and outlet obstruction and one case with recurrent UTI). All our cases were ectopic ureteroceles and were female patients.

Voiding cystourethrogram can demonstrate the size and location of the ureterocele as well as the presence or absence of VUR . Reflux into the ipsilateral lower pole is common, Pfister and colleagues noted an incidence of VUR of $49 \%$.Reflux may also be seen in the contralateral system if the ureterocele is large enough to distort the trigone and the opposite ureteral submucosal tunnel, as also seen in our two cases of duplex ureteroceles associated with bilateral reflux (Fig.1, 2, 3). The remained two cases were with single system and not refluxing. Our two cases with single system were treated by endoscopic puncture alone (Fig. 4, 5.6).

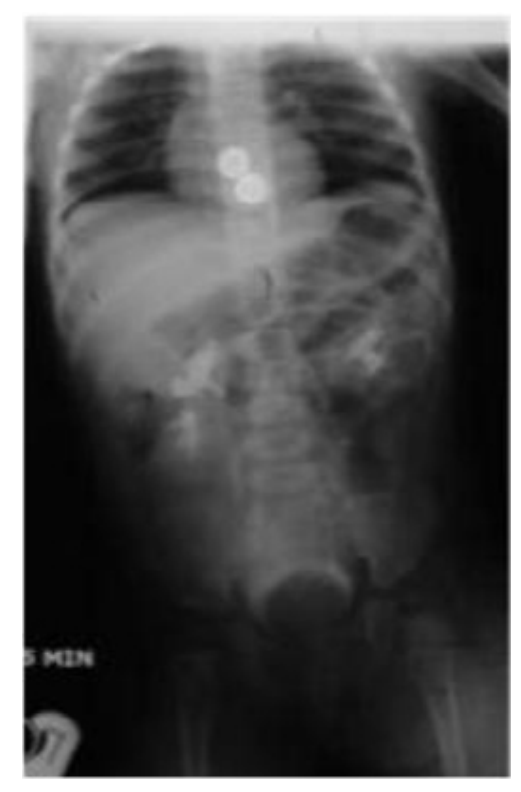

Fig4. IVU: Rt. single ureterocele

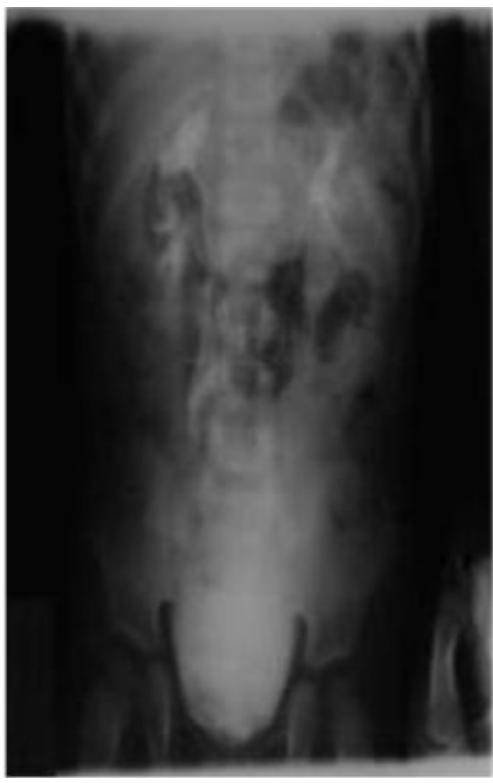

Fig5. Post uretrocele puncture IVU

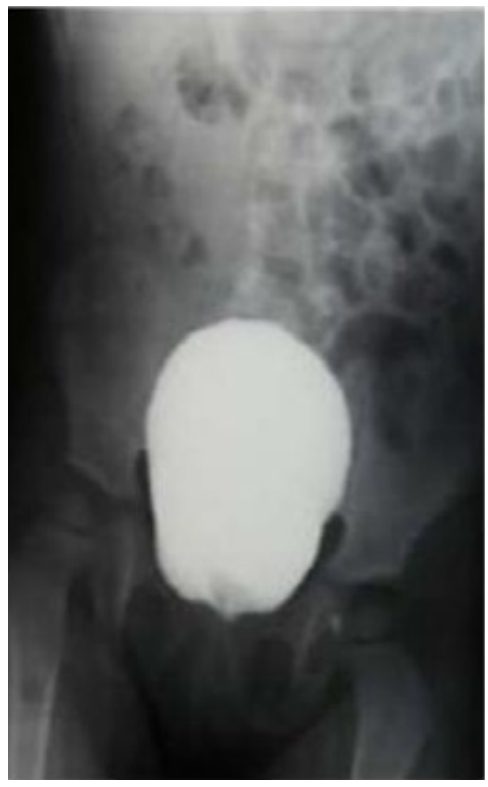

Fig6. Post ureterocele puncture VCUG: No Reflux

While the two with duplicated system were treated, one case with puncture of the ureterocele and ipsilateral heminephrectomy and the other case with opened excision (marsupilization) of huge ureterocele and ipsilateral heminephroureterectomy, Fig. $(7,8,9,10)$ (Reconstructive surgery). As we mentioned in the literature, we chose the suitable options of treatment for each case. They remained asymptomatic and required no further treatment during follow up period of 24 months. 


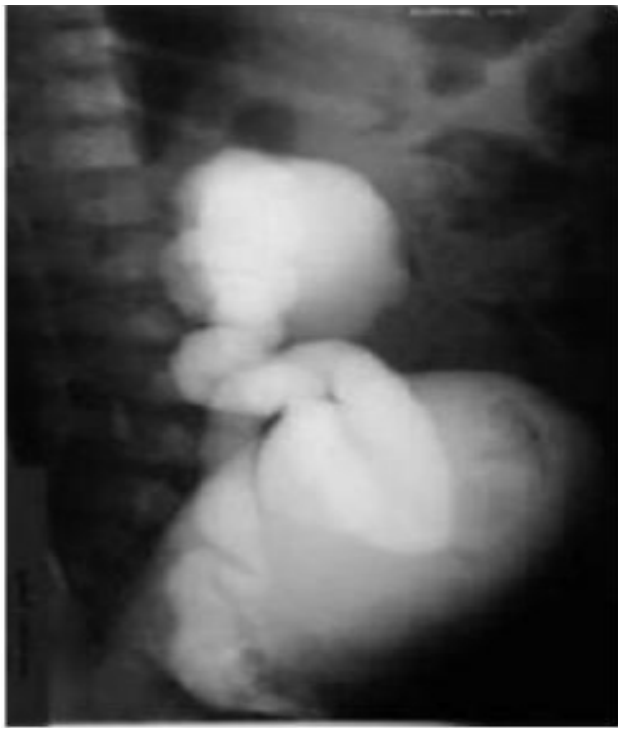

Fig7. VCUG:Severe Rt. VUR post ureterocele marsupilazation

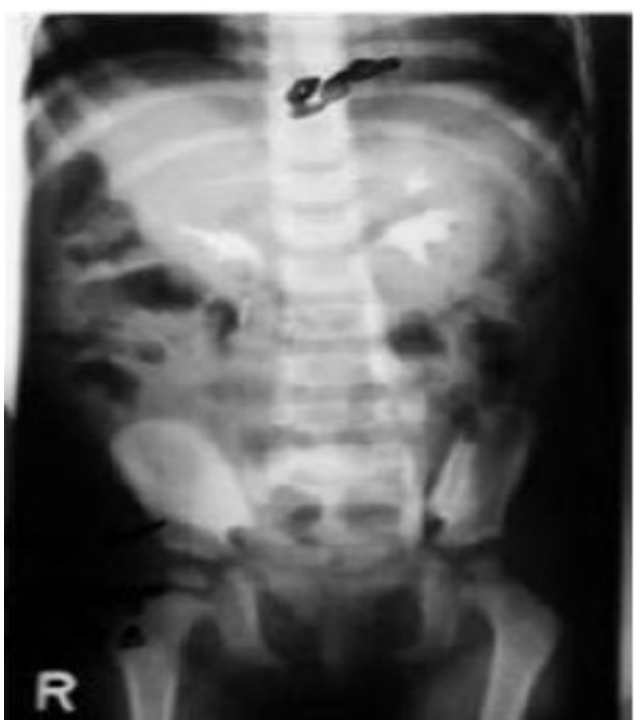

Fig9. IVU:Normal urogram Post Rt. heminephroureterectomy

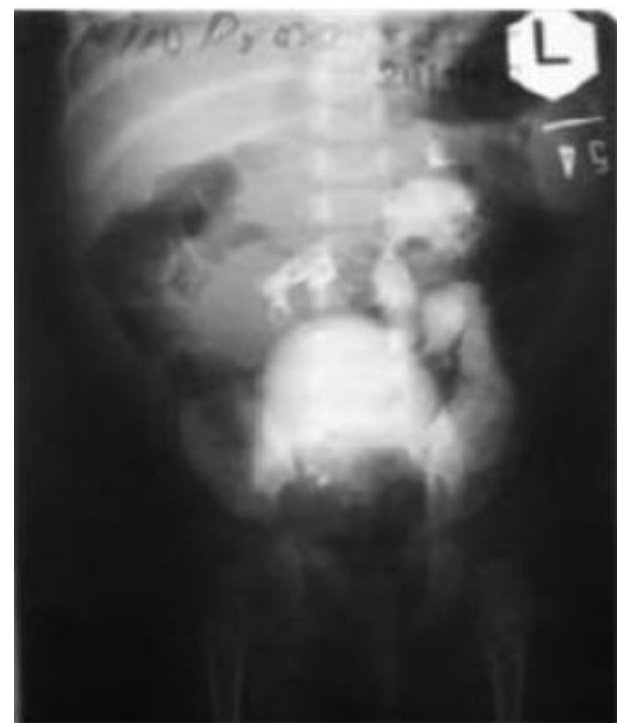

Fig8. IVU: Rt. ectopic ureterocele with bil. duplication system.

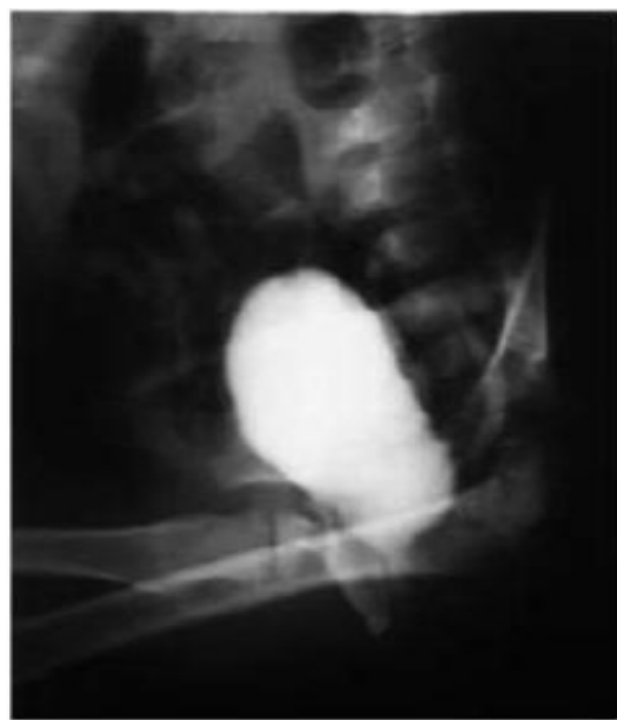

Fig10. VCUG: No reflux post heminephroureterectomy

\section{CONCLUSION}

Treatment of uretroceles is best tailored to the individual case and depends on the extent of the clinical problems, i.e. the presence of obstruction, extravesical ureteral ectopia, duplex system, and VUR and dysplastic hydronephrotic kidney. Transurethral incision of ureterocele effectively relieves the obstruction but may result in VUR necessitating ureteral reimplantation at a later stage. Other forms of surgical intervention require partial nephroureterectomy of the upper moiety. 


\section{REFERENCES}

1. Coplen DE.Management of the neonatal ureterocele .Curr Urol Rep2001; 2:102.

2. DiSandro MJ, Kogan BA. Neonatal management .Role for early intervention. Urol Clin North Am 1998; 25, 187.

3. Schlussel RN, Ratik AB.Ectopic ureter, ureterocele, and other anomalies of the ureter.In: Campbell MF, ed. Campell's Urology.8th Ed Philadelphia: WB saunders: 2003-58.

4. De Foor, W.et al. Ectopic ureterocele: clinical application of classification based on renal unit Jeopardy. J Urol 169, 1092-1094 (2003).

5. Ureteroceles on duplex ureters. In: Stephens F,Smith E,Hustun J, editors. Congenital anomalies of the kidney, urinary and genital tracts. London:Martin Dunitz,2002:243-262.

6. Tanagho EA: Embryologic basis for lower ureteral Anomalies: A hypothesis. Urology 1976; 7:451.

7. Chwalla R. The process of formation of cystic dilation of the vesical end of the ureter and diverticulum at the ureteral ostium. Urol Cutan Rev 1927;31 (8):499

8. Stephens FD: Caecoureterocele and concepts on the embryology and etiology of ureterocele. Aust NZJ Surg 1971; 40:239.

9. Upadhyay, J.et al. Impact of prenatal diagnosis on the morbidity associated with ureteroceles management J.Urol, 197, 2560-2565 (2002).

10. Riba LW. Ureterocele: with case reports of bilateral ureterocele in identical twins. Br. J Urol 1936;8:119-121.

11. Deweerd JH. Feeney DP. Bilateral ureteral ectopia with urinary incontinence in a mother and daughter.J Urol 1967:98:335-337.

12. Babcock JR, Belman AB, Shkoinik A,Ignatoff J. Familial ureteral duplication and ureterocele. Urology 1977;9: 345-349.

13. Ahmeds: prolapsed single system ureterocele in a girl J.Urol 1984; $132: 1180$

14. Coplen, D.E. and Austin, P.F. outcome analysis of prenatally detected ureteroceles associated with multicystic dysplasia .J.Urol. 172, 1637-1639 (2004).

15. Bekker MN ,Vanvugt JM The role of magnetic resonance imging in prenatal diagnosis of fetal anomalies.Eur J Obstet Gynecl Repr Biol 2001:96:173-178.

16. Sozubir S, Lorenzo AJ, Twickler DM, Baker LA, Ewait DH. Prenatal diagnosis of a prolapsed ureterocele with magnetic resonance imaging .Urology 2003;62:144

17. Shinmoto $\mathrm{H}$, Kashima $\mathrm{K}$,Yuaso $\mathrm{Y}$ et al. MR imaging of non-CNS fetal abnormalities : a pictorial essay. Radiographics 2000:20:1227-1243.

18. Nishi T. Magnetic resonance imaging of autosomal recessive polycystic kidney disease in utero. J Obst Gynecol 1995;21:471-474

19. Poutamo J, Vanninen R, Kirkinen P. Diagnosing fetal urinary tract abnormalities: benefits of MRI compared to ultrasonography. Acta Obst Gynecol Scan 2000;79:65-71.

20. Connolly, L.P., Connolly, S.A. Drubach, L.A, ZuraKowski, D. and Ted Treves, ectopic ureteroceles in infants with prenatal hydronephrosis: use of renal cortical scintigraphy. Clin.Nucl.Med.27, 169-175(2002). 
21. Caldamone AA, Synder HM,III,Duckett JW. Ureteroceles in children : follow up of management with upper tract approach. J Urol 1984;131(6);1130-1132.

22. Pohl, H.G.Joyce, G.F., Wise, M.and Cilento, B.G.Jr. vesicoureteral reflux and ureteroceles.J.Urol.177, 1659-1666(2007).

23. Byun E, Merguerian PA. A meta-analysis of surgical practice patterns in the endoscopic management of ureteroceles. J Urol 2006;176 (4Pt 2): 1871-1877.

24. Di Renzo D, Ellsworth Pl, Caldamone AA,Chiesa PL .Trans urethral puncture for ureterocele-which factors dictate outcomes? J Urol 2010; 184(4 Suppl):1620-1624.

25. Husmann, D.A., Strand. W.R., Ewalt, D.H. And Kramer. S.A. Is endoscopic decompression of the neonatal extravesical upper pole ureterocele necessary for prevention of urinary tract infections or bladder neck obstruction? J.Urol.167.1440-1442 (2002).

26. Cooper, C.S et al. Long-term follow up of endoscopic incision of ureteroceles: intravesical versus extravesical. J.Urol.164, 1099-1100 (2000)

27. Husmann, D. et al. management of ectopic ureterocele associated with renal duplication a comparison of partial nephrectomy and endoscopic decompression J.Urol.162, 1406-1409(1999).

28. Castagnetti, M. Cimador, M., Sergio, M.and de Grazia.E .Transurethral incision of duplex system ureteroceles in neonates: Does it increase the need for secondary surgery in intravesical and ectopic cases? BJU 1nt 93, 1313-1217 (2004).

29. Chertin B, De Caluwe D, Puri P. Is primary endoscopic puncture of ureterocele a long-term effective procedure? J Pediatr Surg 2003; 38(1):116-119.

30. Castagnetti M, Cimador M, Sergio M, de Grazia E. Transurethral incision of duplex system ureteroceles in neonates: does it increase the need for secondary surgery in intravesical and ectopic cases? BJU Int 2004; 93(9):13131317.

31. Chertin B ,Mohanan N,Farkas A Puri P Endoscopic treatment of vesicoureteral reflux associated with ureterocele .J Urol 2007;178(4Pt2):1594-1597.

32. Perez-Brayfield M, Kirsch AJ, Hensle TW, Koyle MA, Furness P, Scherz HC. Endoscopic treatment with dextranomer/hyaluronic acid for complex cases of vesicourethral reflux. J Urol 2004; 172(4Pt 2):1614-1616.

33. Ashamead GG, Mercer B, Herbst M, Moodley J ,Bota A, Elder JS. Fetal bladder outlet obstruction due to ureterocele: in utero (colander) therapy. J Ultrasound Med 2004;23(4):565-568.

34. Austin PF, Cain MP, Casale AJ, Hiett AK, Rink RC. Prenatal bladder outlet obstruction secondary to ureterocele. Urology 1998;52(6):1132-1135.

35. Hansen WF, Cooper CS, Yankowitz J. Ureterocele causing anhydramnios successfully treated with percutaneous decompression. Obstet Gynecol 2002; 99(5Pt2):953-956.

36. Soothill PW , Bartha JL. Tizard J Ultrasound-guided laser treatment for fetal bladder outlet obstruction resulting from ureterocle. Am J Obstet Gynecol 2003;188(4):1107-1108.

37. Lowe GJ. Canon SJ .Jayanthi VR. Laparoscopic reconstructive options for obstruction in children with duplex renal anomalies BJU Int.Jan 2008; 101(2):227-30 (Medline).

38. Denes FT, Danilovic A, Srougi M. Outcome of laparoscopic upper-pole nephrectomy in children with duplex systems.J E ndourol 2007; 21 (2) :162-168. 
39. Singh RR, Wagener S, Chandran H. Laparoscopic management and outcomes in non-functioning moieties of duplex kidneys in children J pediatr Urol 2010 ;6(1):66-69.

40. You D, Bang JK, Shim M, Ryu DS, Kim KS. Analysis of the late outcome of laparoscopic heminephrectomy in children with duplex kidneys. BJU Int 2010;106(2):250-254.

41. Sakellaris G, Hennayake S, Cervellione RM, Dickson AP, Gough D. Outcome study of lower pole heminephrectomy in children. Scand J Urol Nephrol 2009; 43(6):482-485.

42. Valla JS, Breaud J,Carfagna L, Tursini S,Steyaert H. Treatment of ureterocele on duplex ureter:upper pole nephrectomy by retroperitoneoscopy in children based on a series of 24 cases .Eur Urol 2003;43(4):426-429.

43. Prieto J, Ziada A, Baker L, Snodgrass W. Ureterureterostomy via inguinal incision for ectopic ureters and ureteroceles without ipsilateral lower pole reflux. J Urol 2009; 181(4):1844-1848.

44. Gonzalez R, Piaggio L. Initial experience with laparoscopic ipsilateral ureteroureterostomy in infants and children for duplication anomalies of the urinary tract. J Urol 2007; 177 (6):2315-2318.

45. Storm Dw, Modi A, A, Janathi VR. Laparoscopic ipsilateral ureteroureterostomy in the management of ureteral ectopia in infants and children. J Pediatr Urol 2010.

46. Decter, R.M, Sprunger, J, K and Holland R.J. Can a single individualized procedure predictably resolve all the problematic aspects of the pediatric ureterocele? J Urol 165, 2308-2310 (2001).

47. Gomes, J., Mendes, M., Castro .R. and Reis, A. Current role of simplified upper tract approach in the surgical treatment of ectopic ureterocele; a single center's experience Eur.Urol.41, 323-327 (2002)

48. Lewis JM, Cheng EY, Campbell JB, Liu DB, Kropp K etal. Complete excision or marsupialization of ureteroceles :does choice of surgical approach affect outcome? J Urol 2008; 180(4suppl):1819-1822 .

49. Direnna, T. and Leonard, M..P. Watchful waiting for prenatally detected ureteroceles. J.Urol. 175, 1493-1495(2006).

50. Han, M.Y. et al. Indications for non operative management of ureteroceles J.Urol. 174, 1652-1655 (2005).

Citation: Dr. Yasin Idweini, MD, Ph.D. "Ectopic Ureterocele in infancy and childhood: Review of literature and report of 4 cases". American Research Journal of Urology; 1(1): 31-40.

Copyright (c) Dr. Yasin Idweini, MD, Ph.D. This is an open access article distributed under the Creative Commons Attribution License, which permits unrestricted use, distribution, and reproduction in any medium, provided the original work is properly cited. 